\title{
Growth Performance and Digestibility in Karadi Lambs Receiving Different Levels of Pomegranate Peels
}

\author{
Sarwar M. Sadq1*, Dereen O. M. Ramzi², Hozan J. Hamasalim1', Karzan A. Ahmed1 \\ ${ }^{1}$ Department of Animal Production, Faculty of Agricultural Sciences, University of Sulaimani, Kurdistan, Iraq \\ ${ }^{2}$ Department of Basic Science, College of Veterinary Medicine, University of Sualimani, Kurdistan, Iraq \\ Email: "sarwarsadq33@gmail.com
}

Received 22 October 2015; accepted 9 January 2016; published 12 January 2016

Copyright () 2016 by authors and Scientific Research Publishing Inc.

This work is licensed under the Creative Commons Attribution International License (CC BY).

http://creativecommons.org/licenses/by/4.0/

(c) (i) Open Access

\begin{abstract}
The objective of current study was to determine the effect of different ratios of pomegranate peel in diets of Karadi lambs $(0 \%, 1 \%, 2 \%$ or $4 \%$ as control, $\mathrm{T} 1, \mathrm{~T} 2$ and $\mathrm{T} 3$, respectively) on body weight, total body gain, average daily gain, daily feed intake and apparent digestibility of nutrients. Sixteen Karadi male lambs weighing $23.29 \pm 0.42 \mathrm{~kg}$ and $4.5-5$ months old randomly divided into equally four treatment groups and individually penned for the period of 63 days. Results indicated that final body weight was significantly $(P<0.05)$ higher in lambs fed $1 \%$ or $2 \%$ pomegranate peel (PP) as compared to lambs fed 4\% PP. The best improvements in total feed intake, total gain, average daily gain and feed conversion ratio (FCR) in lambs fed 1\% PP. The total dry matter (DM), organic matter (OM), crude protein (CP), ether extract (EE), ash, nitrogen free extract (NFE) and metabolizable energy (ME) intake per (body weight $\left.{ }^{0.75}\right)$ increased $(P<0.05)$ significantly in lambs fed 1\% pomegranate peel (PP); however, the crude fiber (CF) intake decreased in lambs fed 1\% PP as compared to other treatments. While, the dry matter digestibility (DMD), crude protein digestibility (CPD), crude fiber digestibility (CFD) and nitrogen free extract digestibility (NFED) were significantly $(P<0.05)$ higher in lambs fed $1 \%$ PP as compared to T2, T3 and control groups. In addition, EED increased significantly in T3 compared to other treatments. In conclusion, it was indicated that addition of pomegranate peel in diet at the rate of $1 \%$ or $2 \%$ had significant effect on Karadi lambs performance and digestibility.
\end{abstract}

\section{Keywords}

Pomegranate Peel, Growth Performance, Digestibility, Karadi Lambs

\footnotetext{
${ }^{*}$ Corresponding author.
}

How to cite this paper: Sadq, S.M., Ramzi, D.O.M., Hamasalim, H.J. and Ahmed, K.A. (2016) Growth Performance and Digestibility in Karadi Lambs Receiving Different Levels of Pomegranate Peels. Open Journal of Animal Sciences, 5, 16-23. 


\section{Introduction}

Pomegranate (Punica granatum L.) family Punicaceae has been cultivated around the world in subtropical and tropical regions such as in Iraq, Iran, California, Turkey, Egypt, Italy, India, Chile and Spain. Pomegranate peels contain a substantial amount of polyphenols such as sugar-bound flavoniods quercetin and kaempferol, flavond, diglycoside, ellagic acid tannin and organic acids. Although polyphenolic compounds may improve animal health, they can also decrease proteolytic activity, therefore, compromise protein digestion [1]. Pomegranate components have attracted attention for their apparent wound-healing properties [2], immunomodulatory activity [3] [4], antibacterial activity [5], and antiatherosclerotic and antioxidative capacities [6].

However, fresh pomegranate biomass contains high levels of moisture and soluble sugars [4], rendering its disposal, drying, or preservation problematic. In a previous study, Shabtay et al. [4] demonstrated that dietary supplementation with fresh pomegranate peels promoted a significant increase in feed intake, with a positive tendency toward increased body weight gain in bull calves. They suggested that the antioxidant and immunomodulatory properties of pomegranate peels might improve immune function, which could benefit calf health. Recent studies also have shown that effect of antioxidant levels in pomegranate peel in lambs fed helps to improve their health and animal performance [7] [8]. The peel packs some of the weight boosting and health enhancing effects of antibiotics and hormones without the detrimental effects and it may yield meat with higher level of beneficial antioxidants [4]. Pomegranate ellagitannin has been identified as the active antioxidant compound and anticancer activities responsible for protecting low density lipoprotein, cholesterol from oxidation in vivo a key step in the pathogenesis of atherosclerosis. Pomegranate peel and its extracts are also being investigated for their potential uses as food biopreservatives, formulation of products in nutraceutical industry and cattle feed [9]. From the above points, it is possible to say that there is no published research which indicates the effects of using pomegranate peels on growth performance and digestibility in Karadi lambs.

The main objectives of this study were to determine the effect of supplementation pomegranate peel to the diet on Karadi lambs performance and apparent digestibility of nutrients.

\section{Materials and Methods}

\subsection{Location of Experiment}

This study was carried out at the Animal Farm, Dept. of Animal Production, Faculty of Agric. Sci. Univ. of Sulaimani, Bakrajo, Sulaimani, Kurdistan, Iraq.

\subsection{Pomegranate Peels Preparation}

Mature pomegranate fruits were washed and chopped manually to separate the seeds and peel. The rind (peels) obtained, chopped into small pieces using a sharp knife and dried in air circulatory tray drier at $60^{\circ} \mathrm{C} \pm 5^{\circ} \mathrm{C}$ for 6 $\mathrm{h}$ till its moisture content reached $12 \%$ - 14\%. Dried pieces were cooled, powdered in a laboratory disc mill to pass through 20 mesh sieve, packed in high density polyethylene bags and stored at ambient temperature $\left(25^{\circ} \mathrm{C}\right.$ $\pm 5^{\circ} \mathrm{C}$ ) until use [10] [11]. The chemical composition namely moisture, crude protein, crude fat, ash, crude fibres and carbohydrates content of pomegranate peels powder are shown in Table 1.

Table 1. Chemical composition of pomegranate peels powder and barley straw.

\begin{tabular}{ccc} 
Item \% & Pomegranate peels & Barley straw \\
\hline Organic matter (OM) & 96.2 & 91.6 \\
Crude protein (CP) & 5.1 & 4.1 \\
Ether extract (EE) & 4.9 & 3.2 \\
Total Ash & 3.7 & 4.4 \\
Crude fiber (CF) & 11.22 & 41.0 \\
Nitrogen free extract (NFE) & 80.5 & 27.92 \\
Metabolizable energy ME (MJ/Kg)
\end{tabular}

"ME was calculated according to Mirzaei-Aghsaghali [17]. ${ }^{* *} \mathrm{ME}$ of barley straw was calculated according to Hassan et al. [18]. 


\subsection{Experiment Diets and Animals}

A total of 16 Karadi male lambs were used. They were weighing $23.29 \pm 0.42 \mathrm{~kg}$ and $4.5-5$ months old. All lambs were individually housed and treated against ecto- and endo-parasites. After an adaptation periods of 14 days, lambs were randomly divided equally in to four treatments for a period of 63 days. Four rations were used in this experiment which contained one of the four levels of pomegranate peels (PP) $(0 \%, 1 \%, 2 \%$, or $4 \%)$. Chemical composition and formulation ingredients' diets are presented in Table 2.

Table 2. Formulation and chemical composition of experimental diets.

\begin{tabular}{|c|c|c|c|c|}
\hline Ingredients (\%) & $\begin{array}{c}\text { Control } \\
0 \% \text { PP }\end{array}$ & $\begin{array}{c}\mathrm{T} 1 \\
1 \% \mathrm{PP}\end{array}$ & $\begin{array}{c}\mathrm{T} 2 \\
2 \% \mathrm{PP}\end{array}$ & $\begin{array}{c}\mathrm{T} 3 \\
4 \% \mathrm{PP} \\
\end{array}$ \\
\hline Barley grain & 40 & 40 & 40 & 40 \\
\hline Wheat barn & 28 & 27 & 26 & 24 \\
\hline Yellow corn & 20 & 20 & 20 & 20 \\
\hline Soybean meal & 10 & 10 & 10 & 10 \\
\hline Pomegranate peels & 0 & 1 & 2 & 4 \\
\hline Salt (NaCl) & 1 & 1 & 1 & 1 \\
\hline Minerals and vitamins & 0.5 & 0.5 & 0.5 & 0.5 \\
\hline Dicalcium phosphate & 0.5 & 0.5 & 0.5 & 0.5 \\
\hline \multicolumn{5}{|l|}{ Chemical composition \% } \\
\hline Organic matter (OM) & 93.7 & 93.77 & 93.81 & 93.87 \\
\hline Crude protein (CP) & 15.7 & 15.6 & 15.5 & 15.3 \\
\hline Ether extract (EE) & 3.12 & 3.12 & 3.13 & 3.14 \\
\hline Total ash & 6.3 & 6.23 & 6.19 & 6.13 \\
\hline Crude fiber (CF) & 7.8 & 7.7 & 7.6 & 7.5 \\
\hline Nitrogen free extract (NFE) & 67.08 & 67.35 & 67.58 & 67.93 \\
\hline Metabolizable energy ME (MJ/Kg) ${ }^{*}$ & 12.63 & 12.65 & 12.67 & 12.69 \\
\hline
\end{tabular}

Means followed by the same letter within a row are not significant $(\mathrm{P}<0.01){ }^{*} \mathrm{ME}(\mathrm{MJ} / \mathrm{kg} \mathrm{DM})=0.012 \mathrm{CP}+0.031 \mathrm{EE}+0.005 \mathrm{CF}+0.014 \mathrm{NFE}$ [19].

Lambs of the control group received basal diet with $0 \% \mathrm{PP}$, whereas lambs in T1, T2 and T3 received PP at a rate of $1 \%, 2 \%$ or $4 \%$ Table 2 . All lambs were fed concentrate at a rate of $3 \%$ of their body weight. The refusal of the diet was collected and weighed daily before offering the feed in the next morning. Barley straw was given ad libitum. Clean water was available constantly. Lambs were weighed at weekly intervals.

\subsection{Digestibility Trial and Feces Collection}

In the last week of the experiment, total feces were collected from each lamb for 7 days. Feces from the individual lambs were collected and weighed every morning by fitting lambs collection bags [12]. The feces were mixed thoroughly by hand and $10 \%$ sub-sample was retained and stored at $-15^{\circ} \mathrm{C}$. At the end of the collection period, the sample of feed and refusal were dried at $65^{\circ} \mathrm{C}$ for $48 \mathrm{~h}$ and feces were dried at $65^{\circ} \mathrm{C}$ until constant weight. The dried samples were ground through $1 \mathrm{~mm}$ mash. Aliquots of the samples from each day were pooled and analyzed chemically. The apparent digestibility coefficient of feed nutrients was determined according to McDonald et al. [13].

\subsection{Chemical Analysis of Experimental Diet}

In this experiment, concentrate diets were used which contained: barely, yellow corn, soy bean meal, vitamins 
and minerals mixture. Barley straw was used as a source of roughage. Samples of feedstuff, offered feed and refusals were dried at $50^{\circ} \mathrm{C}$ until constant weight before chemical analyses. Samples then ground through a $1 \mathrm{~mm}$ screen for chemical analysis. Dry matters (DM), organic matter (OM), ether extract (EE), crude fibre (CF) and nitrogen free extract (NFE) were determined according to FAO [14].

\subsection{Statistical Analysis}

Data were analyzed according to XLSTAT [15] program for one way analysis of variance. Differences among means were carried out by using Duncan's [16] multiple range tests.

Data from experiment were analyzed according to the following model:

$$
Y i j=\mu+t_{i}+e i j
$$

where: Yij = the dependent variable, $\mu=$ overall mean, $T_{i}=$ effect of the treatment ( $i=$ control, $1 \% \mathrm{PP}, 2 \% \mathrm{PP}$ or $4 \% \mathrm{PP}), e i j=$ random residual error.

\section{Results}

\subsection{Final Body Weight, Total Body Gain, Feed Intake and Feed Conversion Ratio}

Final body weight, total body gain, average daily gain, total feed intake, concentrate and barley straw and feed conversion ratio are given in Table 3. Total body gain and average daily gain of lambs were the same for all treatment groups. The final body weight was significantly $(\mathrm{P}<0.05)$ higher in lambs fed $1 \%$ or $2 \%$ pomegranate peel (PP) being $34.9 \mathrm{~kg}$ and $34.2 \mathrm{~kg}$ for T1 and T2, respectively as compared to lambs fed $4 \% \mathrm{PP}(31.7 \mathrm{~kg})$. The difference between T1 and T2 in final body weight was not significant. Total DM intake and feed conversion ratio (FCR) of lambs fed 1\% PP showed better performance compared to other treatment groups. In spite of, all treatment differences were significant $(\mathrm{P}<0.05)$ in barley straw intake and FCR. The best improvement in total gain, average daily gain and FCR in lambs fed $1 \%$ PP (Table 3). However, marginally higher total gain and average daily gain were observed in the T1 (11.5 kg and $182.5 \mathrm{~g} /$ day) followed by T2, control and T3 groups.

Table 3. Effect of different levels of pomegranate peels on animal performance of Karadi lambs.

\begin{tabular}{ccccc}
\hline Parameter & Control 0\% PP & T1 1\% PP & T2 2\% PP & T3 4\% PP \\
\hline Initial body weight (kg) & $23.6 \pm 0.66^{\mathrm{a}}$ & $23.4 \pm 1.29^{\mathrm{a}}$ & $23.5 \pm 1.61^{\mathrm{a}}$ & $23.3 \pm 1.55^{\mathrm{a}}$ \\
Final body weight (kg) & $33.3 \pm 0.38^{\mathrm{ab}}$ & $34.9 \pm 0.58^{\mathrm{a}}$ & $34.2 \pm 0.62^{\mathrm{a}}$ & $31.7 \pm 0.48^{\mathrm{b}}$ \\
Total body gain (kg) & $9.7 \pm 0.75^{\mathrm{a}}$ & $11.5 \pm 1.56^{\mathrm{a}}$ & $10.7 \pm 1.57^{\mathrm{a}}$ & $8.4 \pm 1.80^{\mathrm{a}}$ \\
Average daily gain (g/day) & $153.97 \pm 11.8^{\mathrm{a}}$ & $182.54 \pm 24.8^{\mathrm{a}}$ & $169.84 \pm 24.9^{\mathrm{a}}$ & $133.33 \pm 28.6^{\mathrm{a}}$ \\
Total feed intake (DM g/day) & $1110 \pm 41.4^{\mathrm{b}}$ & $1146 \pm 25.7^{\mathrm{a}}$ & $1115 \pm 59.6^{\mathrm{b}}$ & $1118 \pm 37.5^{\mathrm{b}}$ \\
Concentrate intake (DM g/day) & $789 \pm 17.7^{\mathrm{a}}$ & $797 \pm 13.3^{\mathrm{a}}$ & $792 \pm 13.3^{\mathrm{a}}$ & $799 \pm 17.8^{\mathrm{a}}$ \\
Straw intake (DM g/day) & $321 \pm 8.6^{\mathrm{b}}$ & $349 \pm 22.6^{\mathrm{a}}$ & $323 \pm 13.5^{\mathrm{b}}$ & $319 \pm 6.4^{\mathrm{b}}$ \\
FCR (g DM intake /g LWG) & $7.21 \pm 0.38^{\mathrm{b}}$ & $6.27 \pm 0.41^{\mathrm{c}}$ & $6.57 \pm 0.25^{\mathrm{bc}}$ & $8.39 \pm 0.11^{\mathrm{a}}$ \\
\hline
\end{tabular}

${ }^{\mathrm{a}-\mathrm{c}}$ Means followed by different superscripts within a row are significant $(\mathrm{P}<0.05)$. FCR: Feed conversion ratio; DM: Dry matter; LWG: Live Weight Gain; PP: Pomegranate Peels.

\subsection{Daily Nutrient Intake during Digestibility Trial in Karadi Male Lambs}

Table 4 presented the mean value of metabolic body weight, DM, OM,CP,EE, Ash, CF, NFE and ME intake during digestibility trial in Karadi lambs. The result indicated that total DM, OM, CP, EE, Ash, NFE and ME intake expressed as $\left(\mathrm{g} /\right.$ day and $\left.\mathrm{BW}^{0.75}\right)$ increased $(\mathrm{P}<0.05)$ significantly in lambs fed $1 \%$ pomegranate peel (PP). Except crude fiber (CF) intake decreased in lambs fed 1\% PP as compared to other treatment groups. However, some parameters in the current work (DMI, OMI, CPI and ash intake (g/day)) were almost similar across all treatment groups. But all other parameters expressed as $\left(\mathrm{BW}^{0.75}\right)$ was significantly different among treatment groups. 
Table 4. Effect of different levels of pomegranate peels on daily nutrient intake of Karadi lambs during the digestibility trial.

\begin{tabular}{|c|c|c|c|c|}
\hline Parameter & $\begin{array}{l}\text { Control } \\
0 \% \text { PP }\end{array}$ & $\begin{array}{c}\mathrm{T} 1 \\
1 \% \mathrm{PP}\end{array}$ & $\begin{array}{c}\mathrm{T} 2 \\
2 \% \mathrm{PP}\end{array}$ & $\begin{array}{c}\mathrm{T} 3 \\
4 \% \mathrm{PP}\end{array}$ \\
\hline Metabolic weight $\left(\mathrm{W}^{0.75}\right)$ & $13.49 \pm 0.15^{\mathrm{ab}}$ & $13.89 \pm 0.33^{\mathrm{a}}$ & $13.80 \pm 0.051^{\mathrm{a}}$ & $13.01 \pm 0.021^{b}$ \\
\hline Total DMI (g/day) & $1008 \pm 8.69^{\mathrm{a}}$ & $1024 \pm 5.87^{\mathrm{a}}$ & $1021 \pm 5.76^{\mathrm{a}}$ & $1005 \pm 2.48^{\mathrm{a}}$ \\
\hline DMI (g/kg W $\left.{ }^{0.75}\right)$ & $74.72 \pm 0.66^{\mathrm{b}}$ & $78.71 \pm 0.34^{\mathrm{a}}$ & $73.99 \pm 0.51^{\mathrm{b}}$ & $72.35 \pm 1.67^{\mathrm{b}}$ \\
\hline OMI (g/day) & $944.5 \pm 8.1^{\mathrm{a}}$ & $961.2 \pm 5.5^{\mathrm{a}}$ & $957.8 \pm 5.4^{\mathrm{a}}$ & $942.4 \pm 2.3^{\mathrm{a}}$ \\
\hline OMI (g/kg W $\left.{ }^{0.75}\right)$ & $70.03 \pm 0.62^{\mathrm{b}}$ & $73.88 \pm 0.32^{\mathrm{a}}$ & $69.41 \pm 0.48^{\mathrm{b}}$ & $67.99 \pm 1.56^{\mathrm{b}}$ \\
\hline CP (g/day) & $158.3 \pm 1.4^{\mathrm{a}}$ & $156.7 \pm 0.9^{\mathrm{a}}$ & $158.3 \pm 0.9^{\mathrm{a}}$ & $156.8 \pm 0.4^{\mathrm{a}}$ \\
\hline $\mathrm{CP}\left(\mathrm{g} / \mathrm{kg} \mathrm{W}^{0.75}\right)$ & $11.73 \pm 0.10^{\mathrm{ab}}$ & $12.04 \pm 0.05^{\mathrm{a}}$ & $11.47 \pm 0.08^{\mathrm{b}}$ & $11.31 \pm 0.26^{\mathrm{b}}$ \\
\hline EE (g/day) & $31.45 \pm 0.27^{\mathrm{b}}$ & $32.15 \pm 0.18^{\mathrm{a}}$ & $31.96 \pm 0.18^{\mathrm{ab}}$ & $31.36 \pm 0.08^{\mathrm{b}}$ \\
\hline $\mathrm{EE}\left(\mathrm{g} / \mathrm{kg} \mathrm{W}^{0.75}\right)$ & $2.33 \pm 0.02^{\mathrm{b}}$ & $2.47 \pm 0.01^{\mathrm{a}}$ & $2.32 \pm 0.02^{\mathrm{b}}$ & $2.26 \pm 0.05^{\mathrm{b}}$ \\
\hline Ash (g/day) & $63.5 \pm 0.55^{\mathrm{a}}$ & $62.8 \pm 0.36^{\mathrm{a}}$ & $63.2 \pm 0.36^{\mathrm{a}}$ & $62.6 \pm 0.16^{\mathrm{a}}$ \\
\hline Ash $\left(g / \mathrm{kg} \mathrm{W}^{0.75}\right)$ & $4.71 \pm 0.04^{\mathrm{ab}}$ & $4.83 \pm 0.02^{\mathrm{a}}$ & $4.58 \pm 0.03^{\mathrm{bc}}$ & $4.52 \pm 0.10^{c}$ \\
\hline CF (g/day) & $78.6 \pm 0.68^{\mathrm{a}}$ & $76.8 \pm 0.44^{\mathrm{b}}$ & $77.6 \pm 0.44^{\mathrm{ab}}$ & $77.4 \pm 0.19^{\mathrm{ab}}$ \\
\hline CF $\left(\mathrm{g} / \mathrm{kg} \mathrm{W}^{0.75}\right)$ & $5.83 \pm 0.05^{\mathrm{ab}}$ & $5.90 \pm 0.03^{\mathrm{a}}$ & $5.62 \pm 0.04^{\mathrm{bc}}$ & $5.58 \pm 0.13^{c}$ \\
\hline NFE (g/day) & $676.2 \pm 5.8^{\mathrm{b}}$ & $696.6 \pm 3.9^{\mathrm{a}}$ & $689.9 \pm 3.9^{\mathrm{a}}$ & $676.9 \pm 1.7^{\mathrm{b}}$ \\
\hline NFE $\left(g / k \mathrm{~K} \mathrm{~W}^{0.75}\right)$ & $50.13 \pm 0.44^{\mathrm{b}}$ & $53.47 \pm 0.23^{\mathrm{a}}$ & $50.00 \pm 0.35^{\mathrm{b}}$ & $48.84 \pm 1.12^{\mathrm{b}}$ \\
\hline ME MJ/kg DM & $12.73 \pm 0.11^{\mathrm{b}}$ & $12.99 \pm 0.08^{\mathrm{a}}$ & $12.94 \pm 0.07^{\mathrm{ab}}$ & $12.71 \pm 0.03^{b}$ \\
\hline $\operatorname{ME}\left(\mathrm{g} / \mathrm{kg} \mathrm{W}^{0.75}\right)$ & $0.944 \pm 0.008^{\mathrm{b}}$ & $0.999 \pm 0.004^{\mathrm{a}}$ & $0.937 \pm 0.006^{\mathrm{b}}$ & $0.917 \pm 0.021^{\mathrm{b}}$ \\
\hline
\end{tabular}

${ }^{\mathrm{a}-\mathrm{c}}$ Means followed by different superscripts within a row are significant $(\mathrm{P}<0.05)$.

\subsection{Apparent Digestibility of Nutrients in Karadi Male Lambs}

The apparent digestibility of all nutrients is presented in Table 5. Result indicated that digestibility crude protein (CPD) was significantly $(\mathrm{P}<0.05)$ higher in lambs fed $1 \%$ PP or T1 $(71.7 \%)$, control group $(63.5 \%)$ as compared to T2, T1 (69.2\%, 68.3\%) respectively.

Furthermore, the mean value of ether extract digestibility (EED) was significant $(\mathrm{P}<0.05)$ different among treatment groups, the highest value was found in group lambs fed 4\% PP. But the dry matter digestibility (DMD), crude fiber digestibility (CFD) and nitrogen free extract digestibility (NFED) decreased significantly in lambs fed $4 \%$ pomegranate peel compared to other treatment groups. While, the organic matter digestibility (OMD) was not significant $(\mathrm{P}>0.05)$ among treatment groups. However, OMD marginally showed higher digestibility in control group (67.7\%) followed by T1 (66.8\%), T2 (66.3\%) and T3 (66.1\%). Also, the total digestible nutrient (TDN), digestible energy (DE) and metabolizable energy (ME) are shown in Table 5. No significant were found among treatment groups.

Table 5. Effect of different levels of pomegranate peels on apparent digestibility of nutrient (\%) of Karadi lambs.

\begin{tabular}{ccccc}
\hline Parameter & Control & T1 & T2 & T3 \\
\hline DMD & $68 \%$ PP & $1 \%$ PP & $2 \%$ PP \\
OMD & $67.70 \pm 0.43^{\mathrm{a}}$ & $67.10 \pm 0.62^{\mathrm{a}}$ & $66.40 \pm 0.69^{\mathrm{b}}$ & $65.32 \pm 0.37^{\mathrm{c}}$ \\
CPD & $63.5 \pm 0.87^{\mathrm{c}}$ & $66.80 \pm 0.68^{\mathrm{a}}$ & $66.30 \pm 0.37^{\mathrm{a}}$ & $66.10 \pm 0.56^{\mathrm{a}}$ \\
EED & $60.4 \pm 0.43^{\mathrm{b}}$ & $61.7 \pm 0.71^{\mathrm{a}}$ & $69.2 \pm 0.49^{\mathrm{b}}$ & $68.3 \pm 0.89^{\mathrm{b}}$ \\
CFD & $59.4 \pm 0.59^{\mathrm{a}}$ & $59.1 \pm 0.17^{\mathrm{a}}$ & $61.5 \pm 0.57^{\mathrm{b}}$ & $63.8 \pm 0.69^{\mathrm{a}}$ \\
NFED & $74.7 \pm 0.44^{\mathrm{a}}$ & $74.8 \pm 0.21^{\mathrm{a}}$ & $56.3 \pm 0.37^{\mathrm{b}}$ & $54.6 \pm 0.31^{\mathrm{c}}$ \\
$\mathrm{TDN}^{1}$ & $69.17 \pm 0.44^{\mathrm{a}}$ & $69.72 \pm 0.91^{\mathrm{a}}$ & $69.15 \pm 0.64^{\mathrm{a}}$ & $72.3 \pm 0.69^{\mathrm{b}}$ \\
$\mathrm{DE}^{2}$ & $3.049 \pm 0.131^{\mathrm{a}}$ & $3.074 \pm 0.032^{\mathrm{a}}$ & $3.048 \pm 0.028^{\mathrm{a}}$ & $68.68 \pm 0.56^{\mathrm{a}}$ \\
$\mathrm{ME}^{3}$ & $2.500 \pm 0.137^{\mathrm{a}}$ & $2.520 \pm 0.169^{\mathrm{a}}$ & $2.499 \pm 0.102^{\mathrm{a}}$ & $3.028 \pm 0.023^{\mathrm{a}}$ \\
\hline
\end{tabular}

${ }^{\mathrm{a}-\mathrm{c}}$ Means followed by different superscripts within a row are significant $(\mathrm{P}<0.05)$. DMD = Dry matter digestibility, OMD $=$ Organic matter digestibility, CPD = crude protein digestibility, EED = Ether extract digestibility, CFD = Crude fiber digestibility, NFED = Nitrogen free extract digestibility, ${ }^{1} \mathrm{TDN}(\mathrm{DM})=\mathrm{DCP}+\mathrm{DEE} \times 2.25+\mathrm{TDC}[20] .{ }^{2} \mathrm{DE}=\% \mathrm{TDN} \times 0.04409[21] .{ }^{3} \mathrm{ME}=\mathrm{DE} \times 0.82$ [21]. TDC= Total digestible carbohydrate, TDN $=$ Total digestible nutrient, $\mathrm{DE}=$ Digestible energy, ${ }^{3} \mathrm{ME}=$ Metabolizable energy. 


\section{Discussion}

\subsection{Effect of Addition of Pomegranate Peel on Lambs Performance}

Pomegranate peel (PP) is rich in tannins, which previously shown to have both adverse and beneficial effects in ruminants [7] [22]. Thus, it increased the final body weight, refers by addition of pomegranate peel in the diets. In the present study, $1 \%$ to $2 \%$ PP supplementation increased final body weight in Karadi lambs. Similar results were also reported by Aerts et al., [23] indicated that concentration of tannins (2\% to 4\%) in the diet of sheep improve production efficiency in ruminants such as increased feed intake, body weight gain, wool production, milk yield and ovulation rate. In contrast, the final body weight did not have any change when lambs fed pomegranate peel at the rate $(2 \%, 4 \%$ and $6 \% \mathrm{PP})$ reported by [7]. However, numerically increased the total gain and average daily gain in lambs fed ( $1 \%$ to $2 \% \mathrm{PP})$, it seems that lambs had a best response to addition of $1 \% \mathrm{PP}$ (Table 3).

On the other hand, increased feed intake and feed conversion ratio (FCR) in lambs fed $1 \%$ pomegranate peel as compared to other treatment groups. This also explains the high total feed intake and FCR in this group, which revealed the highest intake (1146 g.day ${ }^{-1}$ and $6.27 \mathrm{~g}$ DM intake/g LWG). This improvement in total feed intake and FCR in lambs fed $1 \%$ PP may be it is more palatability compared to $2 \%$ or $4 \%$ PP because of animal feed selection depends heavily on the palatability of the feed. Tannins are usually associated to a decrease in palatability, and consequently discourage grazing [24]. High tannin levels reduce preference of plants by cattle, sheep and goats [25]. In contrast, Frutos et al. [26] reported no effect of chestnut (Hydrolysable Tannin) HT on DMI and FCR in finishing lambs consuming a high-energy ration (14.2 MJ GE/kg DM). In addition, there are exceptions to tannin suppression of DMI and in some cases there is an increase in DMI due to tannin supplementation [27] [28].

\subsection{Effect of Supplementation Pomegranate Peel on Daily Nutrient Intake during Digestibility Trials in Karadi Lambs}

In our study, the results showed that pomegranate peel (PP) has effect on daily nutrient intake during digestibility trial in Karadi lambs. The mean value of nutrients increased in lambs fed 1\% PP compared to other treatment, due to containing a low level of tannin in lambs fed 1\% PP. Several studies suggested that contents of condensed tannins higher than $50 \mathrm{~g} / \mathrm{kg}$ dry matter (DM) significantly reduce voluntary feed intake, in most ruminants, while medium or low levels seems to have a minor effect [26]. Similar results was found by Jami et al. [29] who showed that using 1\% - 4\% pomegranate peel extract improved DM, CP, and NDF intake and digestibility in dairy cows. Shabtay et al., [4] reported that using pomegranate peel up to $20 \%$ in feedlot calves diet, not only does not possess adverse effects on fattening performance but also because of its palatability, feed intake and consequently average daily gain were increased. They are suggested that tannins are considered to have both adverse and beneficial effects in ruminant animals. High concentrations of tannins may reduce feed intake, digestibility of protein and carbohydrates and animal performance via their negative effects on palatability and digestion.

\subsection{Effect of Supplementation Pomegranate Peel on Apparent Digestibility of Nutrients in Karadi Male Lambs}

The higher digestibility of crude protein (CPD), crude fiber digestibility and nitrogen free extract (NFED) are increased in lambs fed 1\% PP in our study, can be related to the low concentration of tannin in this group. High concentrations of tannins may reduce feed intake, digestibility of protein and carbohydrates and animal performance via their negative effects on palatability and digestion. Low and moderate $(2 \%-4.5 \%)$ concentrations of condensed tannins in the diet improved production efficiency in ruminants, by increasing the flow of non-ammonia nitrogen and essential amino acids from the rumen. In ruminants a particularly important positive effect of tannins is dietary protein protection from ruminal microflora attack [30] [31]. Due to the binding of tannins to dietary protein, and also to a reduction in the activity of a large proportion of microflora, there is an increased rate of amino acid absorption in the intestine, which improves the utilization of nitrogen by ruminants [32]. As well as binding to protein, tannins can also bind to carbohydrates, leading also to a reduction in ruminal gas production [32] [33]. Due to a combination of these activities tannins can be associated with improvements in animal growth and productivity and consequentially minimization of effects to the environment. However, the high digestibility of ether extract (EED) was found in lambs fed $4 \%$ PP, due to tannin was protected the ether 
extract to degrade in the rumen and it is escape and flow rate from rumen in to the small intestine and it is more suitable for absorption [34].

\section{Conclusion}

Supplementation of $1 \%$ or $2 \%$ PP had a significant effect on final body weight, total DM intake, FCR and digestibility of nutrient in Karadi lambs.

\section{References}

[1] Oliveira, R.A., Narciso, C.D., Bisinotto, R.S., Perdomo, M.C., Ballou, M.A., Dreher, M. and Santos, J.E.P. (2010) Effects of Feeding Polyphenols from Pomegranate Extract on Health. Growth, Nutrient Digestion, and Immunocompetence of Calves. Journal of Dairy Science, 93, 4280-4291. http://dx.doi.org/10.3168/jds.2010-3314

[2] Murthy, K.N., Reddy, V.K., Veigas, J.M. and Murthy, U.D. (2004) Study on Wound Healing Activity of Punica granatum Peel. Journal of Medicinal Food, 7, 256-259. http://dx.doi.org/10.1089/1096620041224111

[3] Gracious Ross, R., Selvasubramanian, S. and Jayasundar, S. (2001) Immunomodulatory Activity of Punica granatum in Rabbits. A Preliminary Study. Journal of Ethnopharmacology, 78, 85-87. http://dx.doi.org/10.1016/S0378-8741(01)00287-2

[4] Shabtay, A., Eitam, H., Tadmor, Y., Orlov, A., Meir, A., Weinberg, P., Weinberg, Z.G., Chen, Y., Brosh, A., Izhaki, I. and Kerem, Z. (2008) Nutritive and Antioxidative Potential of Fresh and Stored Pomegranate Industrial Byproduct as Novel Beef Cattle Feed. Journal of Agricultural and Food Chemistry, 56, 10063-10070. http://dx.doi.org/10.1021/jf8016095

[5] Navarro, V., Villarreal, M.L., Rojas, G. and Lozoya, X. (1996) Antimicrobial Evaluation of Some Plants Used in Mexican Traditional Medicine for the Treatment of Infectious Diseases. Journal of Ethnopharmacology, 53, 143-147. http://dx.doi.org/10.1016/0378-8741(96)01429-8

[6] Tzulker, R., Glazer, I., Bar-Ilan, I., Holland, D., Aviram, M. and Amir, R. (2007) Antioxidant Activity, Polyphenol Content, and Related Compounds in Different Fruit Juices and Homogenates Prepared from 29 Different Pomegranate Accessions. Journal of Agricultural and Food Chemistry, 55, 9559-9570. http://dx.doi.org/10.1021/jf071413n

[7] Hussein, S.A.M. and Shujaa, T.A. (2013) The Effect of Using Different Ratios of Pomegranate Peels in Performance and Digestibilities in Awassi lambs. Journal of Tikrit University for Agricultural Sciences, 13, 52-62.

[8] HamaKhan, K.M., Hamasalim, H.J., Sadq, S.M. and Ramzi, D.O.M. (2015) Changes in Lipid Profile and Some Blood Biochemical Parameters in Karadi Lambs Receiving Different Levels of Pomegranate Peels. Research Opinions in Animal and Veterinary Sciences, 5, 210-214.

[9] Seeram, N., Lee, R., Hardy, M. and Heber, D. (2005) Rapid Large Scale Purification of Ellagitannins from Pomegranate Husk, a By-Product of the Commercial Juice Industry. Separation and Purification Technology, 41, 49-55. http://dx.doi.org/10.1016/j.seppur.2004.04.003

[10] Singh, D. and Sethi, V. (2003) Screening of Pomegranate Genotypes for the Preparation of Quality Grade Anardana. Journal of Food Science and Technology, 40, 236-238.

[11] Devatkal, S.K and Naveena, B.M. (2010) Effect of Salt, Kinnow and Pomegranate Fruit By-Product Powders on Color and Oxidative Stability of Raw Ground Goat Meat during Refrigerated Storage. Meat Science, 85, 306-311. http://dx.doi.org/10.1016/j.meatsci.2010.01.019

[12] Hassan, K.M., Sadq, S.M., Zahir, H.G. and Salih, A.M. (2014) Effect of Different Levels of Ground Flaxseed on in Vitro and in Vivo Digestibility in Karadi Lambs. Research Opinions in Animal \& Veterinary Sciences, 4, 644-649.

[13] Mcdonald, P., Edwards, R.A., Greenhalgh, J.F.D. and Morgan, C.A. (2002) Animal Nutrition. 6th Edition, Prentice Hall, Upper Saddle River, 33-47, 176, 270-271, 281-289.

[14] FAO (2011) Quality Assurance for Animal Feed Analysis Laboratories. FAO Animal Production and Health Manual No. 14, Rome.

[15] XLSTAT (2007) Statistical Software for Excel. https://www.xlstat.com

[16] Duncan, D.B. (1955) Multiple Ranges and Multiple "F" Test. Biometrics, 11, 1-42. http://dx.doi.org/10.2307/3001478

[17] Mirzaei-Aghsaghali, A., Maheri-Sis, N., Mansouri, H., Razeghi, M.E., Mirza-Aghazadeh, A., Cheraghi, H. and Aghajanzadeh-Golshani, A. (2011) Evaluating Potential Nutritive Value of Pomegranate Processing By-Products for Ruminants Using in Vitro Gas Production Technique. Journal of Agricultural and Biological Science, 6, 45-51.

[18] Hassan, S.A., Sadq, S.M. and Hassan, K.M. (2012) Evaluation of Fungal or Chemical Treatments for Barley Straw in Ruminants Feeding 1-Chemical Composition, in Vitro, in Vivo Digestibility and Voluntary Intake. Jordan Journal of Agricultural Sciences, 8, 232-241. 
[19] MAFF (Ministry of Agriculture, Fisheries and Food) (1975) Energy Allowances and Feeding Systems for Ruminants. Technical Bulletin 33, Her Majesty's Stationary Office, London.

[20] Sniffen, C.J., O’Connor, J.D., Van Soest, D.G., Fox, D.G. and Russell, J.B. (1992) A Net Carbohydrate and Protein System for Evaluating Cattle Diets: II. Carbohydrate and Protein Availability. Journal of Animal Science, 70, 35623577.

[21] NRC—National Research Council (1996) Nutrient Requirements of Beef Cattle. 7th Edition, National Academy Press, Washington DC.

[22] Makkar, H.P.S. (2003) Effects and Fate of Tannins in Ruminant Animals, Adaptation to Tannins, and Strategies to Overcome Detrimental Effects of Feeding Tannin-Rich Feeds. Small Ruminant Research, 49, 241-256. http://dx.doi.org/10.1016/S0921-4488(03)00142-1

[23] Aerts, R.J., Barry, T.N. and McNab, W.C. (1999) Polyphenols and Agriculture: Beneficial Effects of Proanthocyanidins in Forages. Agriculture, Ecosystems \& Environment, 75, 1-12. http://dx.doi.org/10.1016/S0167-8809(99)00062-6

[24] Ngwa, A.T., Nsahlai, I.V., Bonsi, M.L. (2003) Feed Intake and Dietary Preferences of Sheep and Goats Offered Hay and Legume-Tree Pods in South Africa. Agroforestry Systems, 57, 29-37. http://dx.doi.org/10.1023/A:1022988200484

[25] Perevolotsky, A., Brosh, A., Ehrlich, O., Gutman, M., Henkin, Z. and Holzer, Z. (1993) Nutritional Value of Common Oak (Quercus calliprinos) Browse as Fodder for Goats: Experimental Results in Ecological Perspective. Small Ruminant Research, 11, 95-106. http://dx.doi.org/10.1016/0921-4488(93)90143-6

[26] Frutos, P., Raso, M., Hervás, G., Mantecón, Á.R., Pérez, V. and Giráldez, F. (2004) Is There Any Detrimental Effect When a Chestnut Hydrolysable Tannin Extract Is Included in the Diet of Finishing Lambs? Animal Research, 53, 127136. http://dx.doi.org/10.1051/animres:2004001

[27] Puchala, R., Min, B.R., Goetsch, A.L. and Sahlu, T. (2005) The Effect of a Condensed Tannin-Containing Forage on Methane Emission by Goats. Journal of Animal Science, 83, 182-186.

[28] Beauchemin, K.A., McGinn, S.M., Martinez, T.F. and McAllister, T.A. (2007) Use of Condensed Tannin Extract from Quebracho Trees to Reduce Methane Emissions from Cattle. Journal of Animal Science, 85, 1990-1996. http://dx.doi.org/10.2527/jas.2006-686

[29] Jami, E., Shabtay, A., Nikbachat, M., Yosef, E., Miron, J. and Mizrahi, I. (2012) Effects of Adding a Concentrated Pomegranate-Residue Extract to the Ration of Lactating Cows on in Vivo Digestibility and Profile of Rumen Bacterial Population. Journal of Dairy Science, 95, 5996-6005. http://dx.doi.org/10.3168/jds.2012-5537

[30] Driedger, A. and Hatfield, E. (1972) Influence of Tannins on the Nutritive Value of Soybean Meal for Ruminants. Journal of Animal Science, 34, 465-468.

[31] McNabb, W.C., Waghorn, G.C., Peters, J.S. and Barry, T.N. (1996) The Effect of Condensed Tannins in Lotus pedunculatus on the Solubilisation and Degradation of Ribulose-1,5-bisphosphate Carboxylase (EC 4.1.1.39; Rubisco) Protein in the Rumen and the Sites of Rubisco Digestion. British Journal of Nutrition, 76, 535-549. http://dx.doi.org/10.1079/BJN19960061

[32] Makkar, H.P.S., Blümmel, M. and Becker, K. (1995) In Vitro Effects and Interactions between Tannins, Saponins and Fate of Tannins in the Rumen. Journal of the Science of Food and Agriculture, 69, 481-493. http://dx.doi.org/10.1002/jsfa.2740690413

[33] Silanikove, N., Tagari, H. and Shkolnik, A. (1993) Comparison of Rate Passage, Fermentation Rate and Efficiency of Digestion of High Fiber Diet in Desert Black Bedouin Goats as Compared to Swiss Saanen Goats. Small Ruminant Research, 12, 45-60. http://dx.doi.org/10.1016/0921-4488(93)90037-I

[34] Patra, A.K. and Saxena, J. (2011) Exploitation of Dietary Tannins to Improve Rumen Metabolism and Ruminant Nutrition. Journal of the Science of Food and Agriculture, 91, 24-37. http://dx.doi.org/10.1002/jsfa.4152 